University of Miami

Susan Haack

\title{
COHERENTISM DISCOMPOSED: \\ A CRITIQUE OF BONJOUR'S THE STRUCTURE OF EMPIRICAL KNOWLEDGE
}

\begin{abstract}
Empirical knowledge - if there be any such thing - is distinguished by having as an essential factor [...] something disclosed in experience. [...] There undoubtedly is some logical relation of facts [...] to which the name 'coherence' might aptly be given. [...] But no logical relationship, by itself, can ever be sufficient to establish the truth, or the credibility even, of any synthetic judgement. [Lewis] ${ }^{1}$
\end{abstract}

I think Lewis is quite right to hold that its inability to allow the relevance of experience to justification is an insuperable difficulty for coherentism. Coherentists, however, naturally enough, argue that the difficulty is superable. This paper is a case study of one attempt to overcome it: BonJour's ${ }^{2}$.

BonJour attempts to accommodate experiential input within a coherentist framework by means of the imposition of an additional requirement, the 'Observation Requirement', on justification. This, however, turns out to be ambiguous: on one interpretation it is compatible with coherentism but fails to guarantee experiential input; on the other, it guarantees observational input all right but sacrifices the coherentist character of the theory.

To motivate his theory of justification, which he describes as an internalist coherentism, BonJour relies on an argument by elimination, an argument which presupposes that two dichotomies - foundationalism versus coherentism and internalism versus externalism — between them provide an adequate categorisa-

${ }^{1}$ O. I. Lewis, The Given Element in Empirical Knowledge, Philosophical Review, 61, 1952, pp. 168-175, pp. $168-169$.

2 L. BonJour, The Structure of Empirical Knowledge, Harvard University Press, Cambridge, MA, 1985; I shall also refer to BonJour's Externalist Theories of Empirical Knowledge, Midwest Studies in Philosophy, 5, 1980, pp. 53-74. 
tion of the alternatives available. I have argued elsewhere that the first of these dichotomies is not exhaustive ${ }^{1}$; and the second, in my view, is not robust enough to carry any serious weight at all ${ }^{2}$. So naturally I think BonJour's strategy ill-chosen. Of course, BonJour might, for all that, have a successful theory to offer. In fact, as I shall argue, he does not; in the end his theory succumbs to the familiar objection that coherentism really cannot accommodate experience. But only in the end: BonJour is aware of the potential objection and develops quite a sophisticated manoeuvre to avoid it - a manoeuvre which, however, fails, and fails, perhaps, in ways which reflect the inadequacies of BonJour's map of the logical space of possible theories of justification.

BonJour's is a moderated, degree-of-embedding coherentism, articulated by means of a distinction between local and global levels of justification. At the local level, where the concern is the justification of a single belief within the context of a cognitive system the justification of which is taken for granted, BonJour concedes that support relations look linear. But at the global level, where the concern extends to the justification of the overall system, they are seen to be essentially holistic. Even the justification of a single belief ultimately requires it to be supported by local, linear connections with other beliefs within an overall system which is justified holistically, by means of its coherence. Coherence, as BonJour conceives it, comes in degrees; and depends, not just on the logical consistency of the cognitive system, but also on its degree of probabilistic consistency, the pervasiveness and strength of its internal inferential connections, its degree of freedom from unexplained anomalies, etc.

BonJour's theory is internalist not only in the sense that it makes justification exclusively a matter of relations among a subject's beliefs (in this sense, any coherence theory is internalist) but also in the sense that it requires that the justification of a belief rely on premisses, as BonJour puts it, "possessed by' ${ }^{3}$ the subject himself. This requirement leads BonJour to introduce a principle he calls the 'Doxastic Presumption' and describes as a presupposition of a subject's having any justified beliefs at all: that a believer 'must [...] have an adequate grasp of his total system of beliefs ${ }^{4}$. This is all pretty vague, of course, but fortunately this vagueness will not stand in the way of my critique.

BonJour acknowledges the force of the intuition that an adequate account of the justification of empirical beliefs must allow some role to experience

${ }^{1}$ S. Haack, Theories of Knowledge: An Analytic Framework, Proceedings of the Aristotelian Society, 83, 1982—1983, pp. 143-157.

2 W. P. Alston, Intemalism and Externalism in Epistemology, Philosophical Topics, XVI.1, 1986, pp. 179--221, and An Internalist Externalism, Synthese, 74,1988, pp. 265-283; though I am not sure that Alston has quite got to the bottom of the problem, I am convinced that he is right to question whether there is any simple dichotomy here.

3 See BonJour, Externalist Theories of Empirical Knowledge, p. 55.

4 BonJour, 77ie Structure of Empirical Knowledge, p. 102. 
('observation' is his word - perhaps not the happiest choice, but it will do no harm to use his terminology in what follows). BonJour also acknowledges that there is reason to suspect that a coherence theory, which by definition holds that all justification is inferential, a matter of relations among beliefs, may be in principle incapable of satisfying this requirement. But he thinks that the apparent difficulty can be overcome.

There are two senses, he suggests, in which a belief may be said to be 'noninferential': with respect to its origin and with respect to its justification. There are indeed, BonJour concedes, beliefs which are non-inferential in origin, i.e., beliefs such that what causes the subject to have them in the first place is not an inference from other beliefs of his, but something else - observation or introspection. But there are, he insists, no beliefs which are non-inferential with respect to justification, i.e., beliefs such that what justifies them is something other that their inferential relationships to other beliefs of the subject. One might reasonably feel some unease already: isn't inference, after all, one way of arriving at a belief? BonJour is not as clear as one could wish on this point, but his position seems to be that what matters where justification is concerned is not what prompted the belief originally but what sustains it at the time in question. He also remarks that it is not necessary that the subject have gone explicitly through the inferential steps needed for justification; but it is not enough, he adds, that the inference be 'available' — it must actually be the subject's reason for continuing to hold the belief. None of this is very satisfactory, but my strategy will be to work with it for the present. As the argument develops, it will become clear that BonJour himself cannot consistently maintain the distinction introduced here; but nothing is to be gained, I think, by crossing this bridge before we come to it.

Armed with this distinction, BonJour suggests that beliefs which are noninferential in origin may be justified, inferentially, by means of an argument which appeals to their non-inferential origin; an this, he argues, will make it possible to allow a role to experience ('observation') while remaining faithful to the coherentist conception of justification as exclusively inferential.

At the local level, the justification of an 'observational' belief, say, that there is a red book on the desk in front of me, might go, according to BonJour, like this:

$(1-0)$ I have cognitively spontaneous belief of kind $\mathrm{K}$ that there is a red book on the desk in front of me;

(2-0) conditions $\mathrm{C}$ obtain;

(3-0) cognitively spontaneous beliefs of kind $\mathrm{K}$ in conditions $\mathrm{C}$ are likely to be true;

So: $(4-0)$ [probably] there is a red book on the desk in front of me. 'Cognitively spontaneous' means, in effect, 'non inferential in origin'. 'Kind $\mathrm{K}$ ' in the present context would be something like 'putatively visual', construed as saying something both about the content of the belief and about its etiology.

'Conditions C' might be e.g., to the effect that lighting conditions are normal, that 
I am not under the influence of hallucinogenic drugs, etc.

The adequacy of such a local justification depends in turn on the justifiability of the premisses. (2-0) and (3-0), BonJour argues, being more or less straightforward empirical beliefs, will be justified in what according to his theory is the usual fashion, i.e., by being suitably embedded in a sufficiently coherent beliefset. (1-0), he suggests, is really a conjunction of there claims: (a) that the subject has the belief in question; (b) that it is of kind $\mathrm{K}$; (c) that it is cognitively spontaneous. Subpremiss (a), according to BonJour, is justified by means of the Doxastic Presumption; subpremiss (b) is justified in part - where the content of the belief is concerned - again via the Doxastic Presumption, and in part - where its etiology is concerned - by introspection.

This means that (in strikingly internalist fashion) the justification of 'observational' beliefs always depends in part on the justification of introspective beliefs. At the local level, the justification of an introspective belief, say that I believe that there is a red book on the desk in front of me, might go, according to BonJour, like this:

(1-I) I have a cognitively spontaneous belief of kind $\mathrm{K}^{\prime}$ that I believe that there is a red book on the desk in front of me;

(3-I) cognitively spontaneous beliefs of kind K' are usually true;

So: $\quad(4-\mathrm{I})$ [probably] I believe that there is a red book on the desk in front of me.

(No analogue of $(2-0)$ is needed, BonJour thinks, because the reliability of introspection, unlike the reliability of observation, is not normally sensitive to the conditions obtaining at the time.)

The adequacy of such a local justification is supposed to depend, again, on the justifiability of the premisses. (3-I), according to BonJour, is a more or less straightforward empirical claim, and hence justified in the same way as (3-0); and $(1-\mathrm{I})$, he suggests, may be justified in the same way as $(1-0)$.

BonJour realises that this account of how it is possible for observation to play a role still doesn't establish that observational input is necessary for the justification of empirical beliefs. And it is here that his 'Observation Requirement' comes in. His statement of this requirement, which he describes as a 'regulative metaprinciple' and admits is 'obviously quite vague', runs as follows:

[I]n order for the beliefs in a cognitive system to be even candidates for empirical justification, that system must contain laws attributing a high degree of reliability to a reasonable variety of cognitively spontaneous beliefs (including [...] those kinds of introspective beliefs which are required for the recognition of other cognitively spontaneous beliefs) ${ }^{7}$.

The Observation Requirement is crucial to what BonJour calls the 'metajustification' of his theory of justification; his argument, that is, that his

Ibid., p. 141. 
20 criteria of justification are truth-indicative. Since BonJour accepts a correspondence theory of truth, the thesis at which his metajustification aims is that:

[A] system of beliefs which (a) remains coherent (and stable) over the long run and (b) continues to satisfy the Observation Requirement is likely, to a degree which is proportional to this degree of coherence (and stability) and the longness of the run, to correspond closely to independent reality ${ }^{8}$.

The role of the Observation Requirement in this metajustification, according to BonJour, is that is 'guarantees that the system of beliefs will receive ongoing observational input', which 'provides the basic reason for thinking that a system of beliefs is likely to be true' ${ }^{9}$; for the best explanation of the continued coherence and stability of a system of beliefs in the face of ongoing observational input, he argues, is that the beliefs concerned correspond, at least approximately, to reality.

My target is not this metajustificatory argument as such (though I have my doubts about whether it would withstand detailed critical scrutiny), but the claim that the Observation Requirement guarantees that a system satisfying it receives ongoing observational input, on which the metajustificatory argument depends.

If one looks again at BonJour's statement of the Observation Requirement, an ambiguity reveals itself between what I shall call a doxastic and an experientialist interpretation. On the doxastic interpretation, the Observation Requirement requires that the subject believe that he has cognitively spontaneous beliefs, and that the subject believe that cognitively spontaneous beliefs are generally reliable. On an experientialist interpretation, it requires that the subject have cognitively spontaneous beliefs, and that he believe that cognitively spontaneous beliefs are generally reliable. (In either case, one assumes, since the Observation Requirement is called 'the Observation Requirement', that the 'cognitively spontaneous beliefs' spoken of include beliefs prompted by the subject's sensory experience.) BonJour's statement is exactly ambiguous between these two interpretations: in saying that a system of beliefs 'must contain laws attributing [...] reliability to [...] cognitively spontaneous beliefs' BonJour might or might not be saying that the system must actually contain cognitively spontaneous beliefs. Which interpretation does BonJour really intend? I don't think there is a determinate answer. It is not just that BonJour has expressed himself a bit ambiguously; the ambiguity, presumably unconscious, is masking a serious difficulty for his theory.

There is plenty of further textual evidence to support this diagnosis of equivocation. Introducing his account of the inferential justification of beliefs which are non-inferential in origin, BonJour writes as if the subject's beliefs

« Ibid., p. 171.'

Ibid., p. 170. 
about the origin of his beliefs are true - but then immediately comments, in parenthesis, that he is doing this only for convenience of exposition:

will be convenient to ignore the case in which the belief in question is not a cognitively spontaneous belief in the first place. [...] I will also not trouble to distinguish between the actual facts of each situation and [the subject's] [...] conception thereof, but will simply assume that the latter is in accordance with the former. [...] [A]llowing for the opposite possibility would greatly complicate the discussion, but would not significantly affect the main issue. ${ }^{10}$

On the page immediately following the initial statement of the Observation Requirement, BonJour tells us that the Observation Requirement 'effectively guarantees that a cognitive system which satisfies it will receive at least apparent input from the world' ${ }^{12}$. But by the chapter following the one in which he introduced the Observation Requirement, where he is deploying it as a vital element of his metajustification, 'at least apparent' has conveniently been dropped, and one finds BonJour claiming that ' $[\mathrm{t}]$ he Observation Requirement [...] guarantees that the system of beliefs will receive ongoing observational input ${ }^{\prime 2}$.

I hope it requires no very elaborate argument to back up my claim that in its doxastic version the Observation Requirement (so-called: the term now starts to look tendentious) does not guarantee observational input (either at a time or 'ongoing'). Perhaps it might be suggested that if the doxastic Observation Requirement is satisfied and the subject is justified in some beliefs which are observational in origin, then the subject must not only believe, but believe with justification, that he has beliefs which are observational in origin. This is true; but it is still clearly insufficient to guarantee input from the world. Possibly BonJour is covertly influenced by the apparently reassuring thought that his metajustification establishes that if the subject believes with justification that he has beliefs which are observational in origin, then probably he does have beliefs which are observational in origin. But of course this makes matters no better; for BonJour's metajustification itself relies on the assumption that input from the world is guaranteed if the Observation Requirement is satisfied, so this apparently reassuring though really gives no reassurance at all.

The trickiest part of the argument is to show how, in its experientialist interpretation, the Observation Requirement radically alters the character of BonJour's theory. It will be useful to begin by offering two thumbnail sketches of the accounts of justification resulting from the two interpretations:

First (doxastic) interpretation:

$S$ is justified in believing that $p$ if:

\footnotetext{
10 Ibid., p. 119.

2 Ibid., p. 142.

${ }^{12}$ Ibid., p. 170.
} 
(local level)

(global level)

(1) (i) p is suitably embedded in S's belief-set;

(1) (ii) S's belief-set is coherent and

(1) (iii) (doxastic OR) includes beliefs to the effect that certain beliefs in the set are cognitively spontaneous.

Second (experientialist) interpretation:

$\mathrm{S}$ is justified in believing that $\mathrm{p}$ if:

(local level)

(global level)

(2)

(2) (i) p is suitably embedded in S's belief-set;

(2) (ii) S's belief-set is coherent and

(iii) (experientialist OR) includes cognitively spon taneous beliefs.

The first interpretation yields what BonJour purports to offer: a (strongly) internalist coherentism - which, however, does not guarantee experiential input. The second interpretation yields something which does guarantee experiential input - which, however, is no longer at all the kind of theory BonJour purported to be offering; no longer, in particular, a coherentist theory.

Clause (1) (iii) is purely doxastic, couched purely in terms of relations among the subject's beliefs, and hence entirely consonant with coherentism. Clause (2) (iii), however, is not purely doxastic, not couched purely in terms of relations among a person's beliefs, and hence not compatible with coherentism. For what it says is that that some beliefs in a system are observational in origin is a necessary condition for any belief in the system to be justified. (I note, by the by, that this is of course quite at odds with BonJour's insistence on the distinctness of questions of origin and questions of justification.)

However, though on the second interpretation BonJour's account would not qualify as coherentist, it would not qualify as foundationalist either. I shall assume that it is not just required that the system include some cognitively spontaneous beliefs but in particular that the beliefs the subject believes to be cognitively spontaneous be cognitively spontaneous. (Unless one assumes this, it is hard to make any coherent sense of the second account.) Then we would have, in effect, two classes of belief - those the justification of which depends on their being observational in origin and those the justification of which does not so depend; but the distinction would not correspond to the foundationalists' distinction of basic and derived beliefs. For basic beliefs must be justified otherwise than by the support of further beliefs; whereas in this reconstructed version of BonJour's theory cognitively spontaneous beliefs would depend for their justification on the support of other beliefs as well as on their observational origin.

We feel, in short, a pull towards an intermediate style of theory, neither foundationalist nor coherentist. And this confirms a claim for which I have argued more directly elsewhere: that the most plausible approach to the theory of empirical justification would allow the relevance of experience without requiring any privileged class of beliefs justified by experience alone — would 
be, as I have put it, "foundherentist' ${ }^{13}$. Not that the theory reconstructed on the experientialist interpretation of BonJour's 'Observation Requirement' is exactly like the foundherentist theory I have suggested; it is unlike it, in particular, in requiring a sharp distinction between beliefs which are observational and beliefs which are inferential in origin. But the reconstructed neither-foundationa- list-norcoherentist version of BonJour's theory, allowing, as it does, both a role to experience and pervasive mutual support, is recognisably foundherentist in tendency.

${ }^{13}$ S. Haack, Theories of Knowledge: An Analytic Framework, and Rebuilding the Ship While Sailing on the Water, [in:] Perspectives on Quine, eds. R. Barret and R. Gibson, Blackwell's, Oxford 1990, pp. Ill-127, section 1. 